\title{
Test more or test less: Covid-19 pandemic and asymmetric decision making
}

\author{
Aliyu Aminu Ahmed', Ruqayya Aminu Muhammad² \\ ${ }^{1}$ Evaluation Department, Monitoring and Evaluation Institute, Midland House, \\ 5th Avenue, Gwarimpa, Abuja. Nigeria \\ aliyuaminuahmed@gmail.com \\ $+2348056155435$ \\ ${ }^{2}$ Training Department Office, Monitoring and Evaluation Institute, Midland House, \\ 5th Avenue, Gwarimpa, Abuja. Nigeria \\ info@mandeinstitute.com ; mandetrainer@gmail.com \\ $+2348186030189$ \\ DOI: 10.29322/IJSRP.11.09.2021.p11711 \\ http://dx.doi.org/10.29322/IJSRP.11.09.2021.p11711
}

\begin{abstract}
The COVID-19 pandemic destabilized governments and impacted negatively on national, regional, and local economies. Decision makers were faced with sudden challenges that required radical decisions that impacts directly on people lives. This article presents concepts of decision making and several behavioral decision theories to attempt to explain the decision-making environment and the macroeconomic choices by the Nigerian Government. Normative and descriptive behavioral decision theories (Takemura, 2014) were briefly explained. The paper observed that Nigeria's response to COVID-19 is very slow and the decision to relaxing the lockdown might have been influenced by asymmetric learning from the prior and current economic and social challenges faced by the country and might not be due to empirical evidence and actual medical standard's needs. The policy makers motivation was because of negative experiences. Nevertheless, the risk of opening the economy far outweighs the risk of continued lockdown that could lead to economic meltdown and anarchy. While new variants of COVID-19 are emerging and some countries experiencing resurgence, Nigeria is caught in a dilemma, literally racing against itself. There are potentials for a catastrophic increase in cases of COVID-19 amidst vaccine hesitancy, skepticism, and mistrust of government. Therefore, more innovative approaches are needed to increase COVID-19 tests and vaccination to save lives.
\end{abstract}

Key Words- COVID-19, Vaccination, Decision-making, Asymmetric decision making

\section{INTRODUCTION}

\section{COVID-19 Globally}

The COVID-19 is a zoonotic virus (Mackenzie \& Smith, 2020). The COVID-19 pandemic started in year 2020 and have devastated the entire world in varying proportions. The first case of COVID-19 was recorded on December 31, 2019, and it's linked to Wuhan, China (Aylward \& Liang, 2021). The World Health Organization (WHO) first announced COVID-19 as a world health emergency in January 2020 (Coronavirus, 2021) and later declared a global pandemic on March 11, 2020 (Ibrahim et al., 2020). More than 80 countries closed their borders ("Global Economic Effects of COVID-19", 2021). Globally, lockdowns were widely adopted by countries to curtail the spread of the virus (Ibrahim et al., 2020). In most countries, businesses, schools, places of worship and public buildings were all closed, and people isolated or quarantined.

The COVID-19 negatively impacted economic growth in 2020 beyond anything experienced in nearly a century ("Global Economic Effects of COVID-19", 2021). Globally over 184 million people were diagnosed with COVID-19 with over 4.0 million deaths ("Global Economic Effects of COVID-19", 2021). Estimates indicate that the virus reduced global economic growth in 2020 to an annualized rate of $-3.4 \%$ to $7.6 \%$. Global trade is estimated to have fallen by $5.3 \%$ in 2020 ("Global Economic Effects of COVID-19", 2021). Response to the pandemic was massive across the world, with United States, Mainland China, Canada, United Arab Emirates (U.A.E) and Europe amongst the most resilient countries ("The Covid Resilience Ranking, 2021). Global data indicates that $32 \%$ of the world population have been vaccinate at least once. A total of 4.84 billion doses of the COVID-19 vaccine had been administered by August 2021 (Ritchie et al., 2021).

\section{Nigeria and COVID-19}

Nigeria has an estimated population of 211 million people as of August 2021 , accounting for about $2.64 \%$ of the World Population ("Nigeria Population, 2021) . Nigeria has, as of Friday 20 August 2021, tested 2,648,684 samples for COVID- 
19 out of which the Confirmed Cases were 185,267, Active Cases were 15,100, Discharged Cases were 167,923 and a death toll of 2,244 ("NCDC Coronavirus", 2021). With Nigeria's population it implies that, as of August 2021, only about $1.3 \%$ of the population have been tested for COVID-19. Majority of the confirmed cases were reported in Lagos $(69,698)$ and Abuja $(20,339)$. The two cities represented a total of about $49 \%$ of total confirmed cases in Nigeria ("NCDC Coronavirus", 2021).

Nigeria is not fully prepared to respond to COVID-19 pandemic (Dixit et al., 2021). The country needs over $\$ 330$ million to procure medical equipment, Personal Protective Equipment (PPE), and medicine for COVID-19 control (Dixit et al., 2021), amidst worst economic recession in four decades ("Nigeria's Economy", 2021). There is also poor public perception of the Nigeria's response to the pandemic (Oleribe et al., 2020). Other issues in Nigerian response to the pandemic also includes the low level of testing and testing capacity (Ibrahim et al., 2020).

However, the Nigeria's response to COVID-19 received significant international support to increase testing and especially roll-out its vaccination program. Nigeria since April 2020 has been receiving donation of test kits, personal protective equipment (PPE), oxygen concentrators and vaccines ("UN provides vital supplies for Nigeria", 2021). Nigeria received its first batch of about 3.94 million doses of AstraZeneca/Oxford COVID-19 vaccine since 02 March 2021("COVID-19 vaccines", 2021) from Vaccines Global Access (COVAX) program. The country also received over four million doses of Moderna COVID-19 vaccine on 01 August 2021 from United States Government. A total of 177,600 doses of Johnson \& Johnson COVID-19 vaccines was donated by the African Union on 08 August 2021 as first monthly shipments until 29.8 million doses are completed ("Nigeria receives 177,600", 2021). The private sector, a telecom company MTN, delivered 300,000 doses of the COVID-19 vaccine in July 2021. These shipments of COVID19 vaccines will assist Nigeria to meet its target of vaccinating $70 \%$ of its population by the end of 2022 ("Nigeria: COVID19 vaccine rollout", 2021).

\section{The asymmetric effects of the COVID-19}

As diverse as the countries health systems, so are the differences in the effects of the COVID-19 pandemic. The asymmetric effects of the COVID-19 were both inter and intra country and at individual levels ("The territorial impact of COVID-19", 2021). In Nigeria economic loses such as reduction in tax revenues might have been felt more by States that have high Internally Generated Revenues (IGR) such as Lagos than State that already depended almost entirely on allocations from the federation accounts.

The challenge of the pandemic also led Nigeria, like every other country, to embark on several emergency measures to stop the spread of the virus, this included self-distancing, self-isolation, use of face masks, quarantine of international travelers (Oleribe et al., 2020) and lockdowns (Uzochukwu et al., 2021). While the lockdowns were important the negative impact is screwed This publication is licensed under Creative Commons Attribution CC BY. http://dx.doi.org/10.29322/IJSRP.11.09.2021.p11711 more against the poor. The poor people lacked the resources and social protection to stay indoors for a long time (Oleribe et al., 2020). The lockdowns might have also impacted more on urban dwellers at individual level than rural dwellers. The reason for negative impact on the urban dwellers is that as the lockdown was prolonged it became difficult to convey goods, especially foodstuffs from rural because the country had closed its land borders to all goods prior to the pandemic ("Nigeria's land borders closed", 2021).

The negative impact on the economy forced the government of Nigeria to ease the lockdowns despite advice by health care professionals not to do so. (Ibrahim et al., 2020). Generally lockdowns were intended to reduce the risks of COVID-19 spreading but lifting the lockdown could also signal that all is safe for people to start normal businesses, while the pandemic is not over (Glaeser et al., 2021). According to Ibrahim et $\mathrm{al}(2020)$, there was gradual increase of reported cases of COVID-19 before the lockdown and when people started flouting the lockdown, the numbers of cases were the highest the first day after the lockdown was eased (Ibrahim et al., 2020). The several episodes of easing lockdowns could have also reinforced the perception of the virus is not as dangerous as portrait and could have, in one way or the other, trivialize the entire COVID-19 pandemic response.

Reaction to COVID-19 pandemic varied greatly across the guidelines, while it was easier for people to wear masks but there were reports that vaccine hesitancy is very strong amongst Nigerians ("Nigeria: COVID-19 vaccine rollout", 2021). There were increased perceptions of the pandemic as low risk or somewhat politically motivated. This was evident in mass protests and breaking of warehouses where COVID-19 palliatives were looted. (Ukomadu \& Dabang, 2021). Generally, the medical community is worried about a pending danger as a result if the phased lifting of lockdowns in Nigeria (Ibrahim et al., 2020).

\section{Research Questions}

-Was the decision to ease the lockdown an asymmetric learning response by the policy makers, because of fear not to aggravate the already fragile situation of the country?

- Was the public willingness to continue with normal activities despite the potential dangers of COVID-19 an asymmetric learning response due to myriad challenges and fatalities being experienced in the country?

- Was the decision to lift the lockdown in Nigeria based on empirical and scientific evidence and comparable medical standards worldwide?

\section{BEHAVIORAL DECISION THEORETICAL FRAMEWORK}

\section{Decision making}

The aim of behavioral decision studies is to "identify situations in which people act boldly or timidly in the face of risk and uncertainty" (Hadar \& Fox, 2021). Decision Making can be referred to as "the act of selecting an alternative from a group 
ISSN 2250-3153

of alternatives, i.e., the choice of action" (Takemura, 1996). In decision making the knowledge of the decision-making environment is important, and this can be (a) Decision making under certainty (b) Decision making under risk and (c) Decision making under uncertainty. The decision making under uncertainty can be (in)Decision making under ambiguity and (ii) Decision making under ignorance (Takemura, 2014; Takemura, 1996). There are many theories to explain decisionmaking which can be categorized into two groups (a) Normative Theories: theories supporting rational decisionmaking example of which is Utility Theory and (b) Descriptive theories: theories that describe how people make decisions , example of which is behavioral decision theory (Takemura, 2014). There is also Prospect Theory which claims that "people do not always show a numerical evaluation of probabilities, but that outcomes are valued according to two aspects: a reference point (reference-dependent value) and an absolute utility" (Reuter \& Montag (2016). Generally, in decision making, people are more inclined to loss aversion, that is they grant more weight to losses than to gains (Reuter \& Montag, 2016). There are mainly two categories of decision strategies which are compensatory and non-compensatory. A compensatory strategy examines information compared to all possible alternatives and the attribute with low assessment value is compensated by other attributes with a high value The noncompensatory has no compensatory relation(Takemura, 2014). It is also important to highlight here that there are various Decision Strategies which includes Additive strategy, Additive difference strategy, Conjunctive strategy, Disjunctive strategy, Lexicographic strategy, and Elimination by aspects strategy (Takemura, 2014).

\section{Asymmetric learning}

According to Merriam-Webster Dictionary "Asymmetry" was first used in 1651. The word "Asymmetry" means "lack of coordination of two parts acting in connection with one another" (Merriam-Webster, n.d.). The concept of asymmetric learning can be viewed in multiple dimensions. In Economics, Asymmetric Information Theory claims that "an imbalance of information between buyers and sellers can lead to market failure". The theory argues that "low-quality and high-quality product can command same price, given a lack of information on the buyer's side" (Ross, 2021).

\section{FINDINGS AND DISCUSSIONS}

Nigeria is already the poverty capital of the world ("Nigeria: Poverty Capital", 2021) with consecutively dwindling financial resources; increased inflation ("Nigeria- Inflation rate 2026 | Statista", 2021); mounting debts ("Total Public Debts", 2021); experiences regular terrorist attacks that claim scores or lives ("Terrorism - Nigeria travel advice", 2021); and road accidents fatalities that is much higher than ten times COVID-19 deaths so far recorded annually ("Fifth United Nations Global Road Safety Week", 2021).

This publication is licensed under Creative Commons Attribution CC BY. http://dx.doi.org/10.29322/IJSRP.11.09.2021.p11711
Economically Nigeria as a country experienced several macroeconomic shocks prior to COVID-19 pandemic, this could contribute to decisions of its leadership to avoid risky financial choices of continuing lockdowns. As indicated by Malmendier and Nagel (2011) "Individuals in cohorts that experienced bad macroeconomic conditions subsequently avoid risky financial choices, either as investors "(Malmendier and Nagel 2011) or as managers (Malmendier and Tate 2005; Malmendier, Tate, and Yan 2011).

In decision making, potential outcomes of decisions are not known in advance but must be learned from experience (Hadar \& Fox, 2021). The main stream media is awash with COVID19 messages, through numerous channels of communication that is intended to encourage the citizens to understand the challenges of the pandemic and encourage them to wear face masks, wash hands, stay at home, enhance cleanness, go for COVID-19 testing, and get vaccinated. ("COVID-19 and Your Health", 2021). While the government and concerned organization were intensifying campaigns through mass media, there are also anti-vaccine groups spreading negative messages against the COVID-19 vaccination through especially social media and protests, undermining the government efforts and prolonging the pandemic("Anti-vax groups", 2021).

The conflicting and asymmetrical messages Nigerian citizens receive, mostly from foreign sources and through social media, could contribute to promoting further suspicion of the government decisions on lockdowns, mass testing as well the vaccinations. At the onset of the COVID-19 pandemic, the government officials appeared to be making decisions with little or no expert advice (Uzochukwu et al., 2021) and policies were basically designed to replicate models of care from highincome countries (Uzochukwu et al., 2021).

Nigerians were, prior to the COVID-19, already in the negative domain considering all the negativities of poverty, fatalities of insurgency, kidnappings, banditry, accidents, robberies and so on. On the other hand, how the mass media presents the daily international COVID-19 fatalities of other Nations is not exactly what is seen in Nigeria.

The fatalities of COVID-19 in Nigeria are negligible compared to the deaths reported by other diseases. For instance, in 2019 prior to COVID-19, Nigeria accounted for almost 23\% of over 411,000(2018 data) malaria deaths ("Fact sheet about Malaria", 2021), there are also high cholera deaths, ("Cholera in Nigeria", 2021), HIV/AIDS mortality, ("CDC Global Health - Nigeria", 2021 ) and so on. The health care system is weak in both funding and capacity, consequently the COVID-19 situation met Nigeria in a fragile situation.

There is a mixture of feelings of anger, mistrust, and confusion regarding the lockdowns. This might have contributed to the asymmetric learning response by the policy makers for fear of not aggravating the already fragile situation. The public willingness to continue with normal activities despite the potential dangers of COVID-19 might have also been due to limited ability to stock basic needs (especially food) for use 
ISSN 2250-3153

during the lockdowns. In one way, the people that are already living in abject poverty and needed to go out daily to work and be able to eat. In another way, the increased stay at home, would exacerbate hunger and starvation, which started manifesting in various forms of domestic and group violence. The decision to neglect the lockdown guidelines by the citizens could be due to asymmetric learning response to the domestic realities and challenges they face.

\section{CONCLUSION}

Nigeria's response to COVID-19 is very slow and the decision to relaxing the lockdown might have been influenced by asymmetric learning from the prior and current economic and social challenges faced by the country and might not be due to empirical evidence and actual medical standard's needs. The policy makers motivation was because of negative experiences. Nevertheless, the risk of opening the economy far outweighs the risk of continued lockdown that could lead to economic meltdown and anarchy. While new variants of COVID-19 are emerging and some countries experiencing resurgence, Nigeria is caught in a dilemma, literally racing against itself. There are potentials for a catastrophic increase in cases of COVID-19 amidst vaccine hesitancy, skepticism, and mistrust of government. Therefore, more innovative approaches are needed to increase COVID-19 tests and vaccination to save lives.

\section{REFERENCES}

[1] Anti-vax groups rack up victories against Covid-19 push. POLITICO. (2021). Retrieved 22 August 2021, from https://www.politico.com/news/2021/06/14/anti-vax-groups-covidvictories-493482.

[2] Aylward, B., \& Liang, W. (2021). Report of the WHO-China Joint Mission on Coronavirus Disease 2019 (COVID-19). Who.int. Retrieved 21 August 2021, from https://www.who.int/docs/defaultsource/coronaviruse/who-china-joint-mission-on-covid-19-finalreport.pdf.

[3] Cholera in Nigeria: Urgent call to strengthen Water, Sanitation and Hygiene (WaSH) - Nigeria. ReliefWeb. (2021). Retrieved 22 August 2021, from https://reliefweb.int/report/nigeria/cholera-nigeria-urgentcall-strengthen-water-sanitation-and-hygiene-wash.

[4] Coronavirus (2021). Coronavirus: COVID-19 Is Now Officially A Pandemic, WHO Says Retrieved 20 August 2021, from https://www.npr.org/sections/goatsandsoda/2020/03/11/814474930/CO VID-19-COVID-19-is-now-officiallya-pandemic-who-says

[5] COVID-19 and Your Health. Centers for Disease Control and Prevention. (2021). Retrieved 22 August 2021, from https://www.cdc.gov/coronavirus/2019-ncov/prevent-gettingsick/prevention.html.

[6] COVID-19 vaccines. Unicef.org. (2021). Retrieved 20 August 2021, from https://www.unicef.org/nigeria/press-releases/covid-19-vaccinesshipped-covax-arrive-nigeria.

[7] Dixit, S., Ogundeji, Y., \& Onwujekwe, O. (2021). How well has Nigeria responded to COVID-19? Brookings. Retrieved 21 August 2021, from https://www.brookings.edu/blog/future-development/2020/07/02/howwell-has-nigeria-responded-to-covid-19/.

[8] Fact sheet about Malaria. Who.int. (2021). Retrieved 22 August 2021, from https://www.who.int/news-room/fact-sheets/detail/malaria.

[9] Fifth United Nations Global Road Safety Week. WHO | Regional Office for Africa. (2021). Retrieved 20 August 2021, from https://www.afro.who.int/news/fifth-united-nations-global-road-safetyweek-nigerian-government-re-commits-road-safety.

[10] Glaeser, E., Jin, G., Leyden, B., \& Luca, M. (2021). Learning From Deregulation: The Asymmetric Impact of Lockdown and Reopening on Risky Behavior During COVID-19.

This publication is licensed under Creative Commons Attribution CC BY. http://dx.doi.org/10.29322/IJSRP.11.09.2021.p11711
[11] Global Economic Effects of COVID-19. Fas.org. (2021). Retrieved 20 August 2021, from https://fas.org/sgp/crs/row/R46270.pdf.

[12] Hadar, L., \& Fox, C. R. (2009). Information asymmetry in decision from description versus decision from experience. Judgment and Decision Making, 4, 317-325. http://journal.sjdm.org/9331/jdm9331.html.

[13] Ibrahim, R., Ajide, K., \& Olatunde Julius, O. (2020). Easing of lockdown measures in Nigeria: Implications for the healthcare system. Health Policy $\begin{array}{lll}\text { and } & \text { Technology, } & \text { 399-404. }\end{array}$ https://doi.org/10.1016/j.hlpt.2020.09.004

[14] KUHNEN, C. (2015). Asymmetric Learning from Financial Information. The Journal of Finance, 70(5), 2029-2062 https://doi.org/10.1111/jofi.12223

[15] Mackenzie, J., \& Smith, D. (2020). COVID-19: a novel zoonotic disease caused by a coronavirus from China: what we know and what we don't. Microbiology Australia, 41(1), 45. https://doi.org/10.1071/ma20013

[16] Malmendier, U., and G. Tate. 2005. CEO overconfidence and corporate investment. Journal of Finance 60:2661-700.

[17] Malmendier, U., and S. Nagel. 2011. Depression babies: Do macroeconomic experiences affect risk-taking? Quarterly Journal of Economics 126:373-416.

[18] Malmendier, U., G. Tate, and J. Yan. 2011. Overconfidence and early-life experiences: The effect of managerial traits on corporate financial policies. Journal of Finance 66:1687-733.

[19] Merriam-Webster. (n.d.). Asymmetry. In Merriam-Webster.com dictionary. Retrieved August 22, 2021, from https://www.merriamwebster.com/dictionary/asymmetry

[20] Nber.org. Retrieved 20 August 2021, from https://www.nber.org/system/files/working_papers/w27650/w27650.pdf

[21] NCDC Coronavirus. Covid19.ncdc.gov.ng. (2021). Retrieved 20 August 2021, from https://covid19.ncdc.gov.ng/.

[22] Nigeria- Inflation rate 2026 | Statista. Statista. (2021). Retrieved 20 August 2021, from https://www.statista.com/statistics/383132/inflationrate-in-nigeria/.

[23] Nigeria Population. Worldometers.info. (2021). Retrieved 20 August 2021, from https://www.worldometers.info/world-population/nigeriapopulation.

[24] Nigeria receives 177,600 . WHO | Regional Office for Africa. (2021). Retrieved 20 August 2021, from https://www.afro.who.int/news/nigeriareceives-177600-doses-johnson-johnson-vaccines-next-phase-covid-19vaccinations.

[25] Nigeria: COVID-19 vaccine rollout kicks off in Africa's most populous country. Africa Renewal. (2021). Retrieved 20 August 2021, from https://www.un.org/africarenewal/magazine/april-2021/nigeria-covid19-vaccine-rollout-kicks-africas-most-populous-country

[26] Nigeria: Poverty Capital. end Poverty. (2021). Retrieved 20 August 2021, from https://www.endpoverty.org/blog/nigeria-poverty-capital-of-theworld.

[27] Nigeria's Economy Faces Worst Recession in Four Decades says New World Bank Report. (2021). Retrieved 22 August 2021, from https://www.worldbank.org/en/news/press-release/2020/06/25/nigeriaseconomy-faces-worst-recession-in-four-decades-says-new-world-bankreport.

[28] Nigeria's land borders closed to all goods; official confirms. Aljazeera.com. (2021). Retrieved 22 August 2021, from https://www.aljazeera.com/economy/2019/10/15/nigerias-land-bordersclosed-to-all-goods-official-confirms

[29] Oleribe, O., Ezechi, O., Osita-Oleribe, P., Olawepo, O., Musa, A., \& Omoluabi, A. et al. (2020). Public perception of COVID-19 management and response in Nigeria: a cross-sectional survey. BMJ Open, 10(10), e041936. https://doi.org/10.1136/bmjopen-2020-041936

[30] Reuter, M., \& Montag, C. (2016). Neuroeconomics. Springer-Verlag.

[31] Ritchie, H., Mathieu, E., Rodés-Guirao, L., Appel, C., Giattino, C., \& Ortiz-Ospina, E. et al. (2021). Coronavirus Pandemic (COVID-19). Our World in Data. Retrieved 20 August 2021, from https://ourworldindata.org/covid-vaccinations?country=OWID_WRL

[32] Ross, S. (2021). What Is the Economic Theory of Asymmetric Information?. Investopedia. Retrieved 22 August 2021, from https://www.investopedia.com/ask/answers/042415/what-theoryasymmetric-information-economics.asp. 
[33] Takemura, K. (1996). Ishikettei to Sono Shien [Decision-making and support for decision-making]. In S. Ichikawa (Ed.), Ninchi Shinrigaku 4kan Shiko [Cognitive psychology vol. 4 thoughts] (pp. 81-105). Tokyo: University of Tokyo Press.

[34] Takemura, K. (2014). Behavioral Decision Theory. https://doi.org/10.1007/978-4-431-54580-4

[35] Terrorism - Nigeria travel advice. GOV.UK. (2021). Retrieved 20 August 2021, from https://www.gov.uk/foreign-travel-advice/nigeria/terrorism.

[36] The Covid Resilience Ranking (2021). Retrieved 21 August 2021, from https://www.bloomberg.com/graphics/covid-resilience-ranking/.

[37] The territorial impact of COVID-19: Managing the crisis across levels of government. OECD. (2021). Retrieved 22 August 2021, from https://www.oecd.org/coronavirus/policy-responses/the-territorialimpact-of-covid-19-managing-the-crisis-across-levels-of-government$\mathrm{d} 3 \mathrm{e} 314 \mathrm{e} 1 /$

[38] Total Public Debts. Dmo.gov.ng. (2021). Retrieved 20 August 2021, from https://www.dmo.gov.ng/debt-profile/total-public-debt.

[39] Tuberculosis CDC Global Health - Nigeria. Cdc.gov. (2021). Retrieved 22 August 2021, from https://www.cdc.gov/globalhealth/countries/nigeria/default.htm.

[40] Ukomadu, A., \& Dabang, P. (2021). In Nigeria, looters target government warehouses stocked with COVID-19 relief. U.S. Retrieved 22 August 2021, from https://www.reuters.com/article/uk-health-coronavirusnigeria-food-idUKKBN27P0YZ.

[41] UN provides vital supplies for Nigeria Government's COVID-19 response. Unicef.org. (2021). Retrieved 21 August 2021, from https://www.unicef.org/nigeria/press-releases/un-provides-vitalsupplies-nigeria-governments-covid-19-response.

[42] Uzochukwu, B., Ruiz, F., Chalkidou, K., Idiong, E., \& Hollingworth, S. (2021). Is Nigeria Ready to Leave Lockdown?. Center For Global Development. Retrieved 21 August 2021, from https://www.cgdev.org/blog/nigeria-ready-leave-lockdown

\section{AUTHORS}

First Author - Aliyu Aminu Ahmed, PhD Student, University of Zambia aliyuaminuahmed@gmail.com +2348056155435

Second Author - Rukayya Aminu Muhammad mandetrainer@gmail.com Correspondence Author - Aliyu Aminu Ahmed, PhD Student,

aliyuaminuahmed@gmail.com +2348056155435 